\title{
Treatment of median arcuate ligament syndrome: outcome of laparoscopic approach
}

\author{
Tratamento da síndrome do ligamento arqueado mediano: resultado da abordagem laparoscópica \\ Julio Cezar Uili COELHO ${ }^{1 \oplus}$, Andréa Virmond El HOSNI ${ }^{1 \oplus}$, Christiano MarloPaggi CLAUS $^{1 \oplus}$, Yan Sacha \\ Hass AGUILERA $^{1 \oplus}$, Gisele Pitrowsk ABOT ${ }^{1 \oplus}$, Alexandre Teixeira Coutinho de FREITAS $^{1 \oplus}$, Marco Aurélio \\ Raeder da COSTA $^{1}{ }^{\circ}$
}

\begin{abstract}
Background: Median arcuate ligament syndrome(MALS) is a rare condition thatmay cause significant clinical manifestations, including abdominal pain and weight loss. Its diagnosis may be difficult and very often delayed. The laparoscopic approach became the standard treatment of MALS. Aim: To assess the outcome of laparoscopic treatment in patients with MALS. Method: The data of sixpatients with MALS who were subjected to laparoscopic sectioning of the median arcuate ligament were retrospectively reviewed. The following data were evaluated: age, gender, clinical and diagnostic tests findings, ASA score, operative findings and complications, postoperative complications and mortality, hospital stay duration, and hospital readmission.The diagnosis of MALS was established by CT angiography and/or MR angiography. Results:There were four (66.7\%) women and two (33.3\%) men aged from 32 to 60 years. The main symptoms were epigastric pain (100\%) and weight loss (66.7\%). The findings of high-grade stenosis of the proximal celiac axis and poststenotic dilation confirmed on angiography confirmed the diagnosis in all patients. Surgical procedure was uneventful in all patients. The only postoperative complication was urinary retention that occurred in a male. At three-month follow-up, all patients were asymptomatic. Conclusion: Laparoscopic treatment of MALS is safe and effective in relieving the clinical manifestations of patients.

HEADINGS: Median arcuate ligament syndrome. Celiac axis compression syndrome. Celiac artery. Laparoscopic surgery.
\end{abstract}

RESUMO - Racional: A síndrome do ligamento arqueado mediano (SLAM) é condição rara que pode causar manifestações clínicas significativas, incluindo dor abdominal e perda de peso. Seu diagnóstico pode ser difícil e muitas vezes estabelecido tardiamente. A abordagem laparoscópica tornou-se o tratamento padrão para ela. Objetivo: Avaliar o resultado do tratamento laparoscópico em pacientes com SLAM. Método: Os dados de seis pacientes com SLAM submetidos a ressecção laparoscópica do ligamento arqueado mediano foram revisados retrospectivamente. Os seguintes dados avaliados foram: idade, gênero, resultados dosexames clínicos e complementares, escore ASA, achados e complicações operatórias, complicações e mortalidade pós-operatórias, tempo de internação e readmissão hospitalar. O diagnóstico de SLAM foi estabelecido por angiotomografia e/ou angiorressonância. Resultados: Havia quatro (66,7\%) mulheres e dois (33,3\%) homens com idades entre 32 e 60 anos. Os principais sintomas foram dor epigástrica (100\%) e perda de peso $(66,7 \%)$. Os achados de estenose de alto grau do tronco celíaco proximal e dilatação pós-estenótica observados na angiografia confirmaram o diagnóstico em todos os pacientes. O procedimento cirúrgico transcorreu sem intercorrências em todos os pacientes. A única complicação pós-operatória foi retenção urinária, que ocorreu em um homem. No seguimento de três meses, todos os pacientes estavam assintomáticos. Conclusão: O tratamento laparoscópico da SLAM é seguro e eficaz no alívio das manifestações clínicas dos pacientes.

DESCRITORES: Síndrome do ligamento arqueado mediano. Síndrome da compressão do tronco celíaco. Artéria celíaca. Cirurgia laparoscópica.

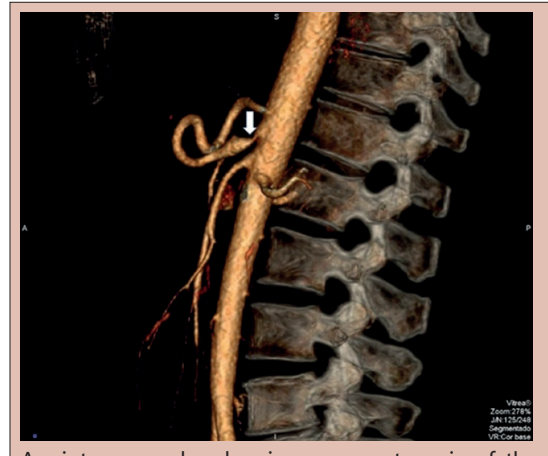

Angiotomography showing severe stenosis of the proximal segment of celiac axis (arrow).

Central Message

Laparoscopic access is safe and effective in the treatment of compression of the celiac axis and/or celiac ganglion by the median arcuate ligament.
Correspondence:

Julio C.U. Coelho

Email: coelhojcu@yahoo.com.br
Financial source: none

Conflict of interest: none

Received for publication: 13/01/2020

Accepted for publication: 28/01/2020

\begin{tabular}{|l|}
\hline Perspective \\
\hline Median arcuate ligament syndrome may cause \\
important symptoms such as abdominal pain, \\
weight loss, nausea and vomiting, and diarrhea.This \\
manuscript shows that adequate selection of patients \\
is very important to improve surgical treatment \\
outcome.This syndrome may be treatedeffectively \\
and with a low rate of complications with the \\
laparoscopic section of the median arcuate ligament.
\end{tabular}


INTRODUCTION

M edian arcuate ligament syndrome(MALS) also namedDunbar syndrome or celiac axis compression syndrome - is due to compression of the celiac axis and/or celiac ganglion by the median arcuate ligament of the diaphragm ${ }^{1,3,15,20}$. It was first described by Harjola $^{6}$ in 1963 who reported resolution of postprandial upper abdominal pain and epigastric bruit in a man following surgical decompression of the celiac axis due to a fibrous celiac ganglion.Dunbar et al ${ }^{4}$ in 1965 reported a series of 15 patients with abdominal angina due to partial celiac artery compression by the median arcuate ligament. Thirteen of these 15 patients underwent surgical decompression of the celiac artery and had relief of abdominal pain.

Although the incidence of median arcuate ligamentsyndrome is unknown, case and series reportsit have increased in the last years, possibly due to widespread use of imaging exams, such as computed tomography and magnetic resonance $2,5,7-10$. It may cause various clinicalsymptoms such as abdominal pain, weight loss, nausea and vomiting, and diarrhea. The pain isvariable and it may be mainly postprandial and alleviated by leaning the body forward ${ }^{11-14}$.In athletes, the pain may be exercise-induced rather than postprandial 7 . Epigastric bruit may be recognized during physical examination. Severe complications such as ruptured pseudo-aneurysm of the inferior pancreatic-duodenal artery have also been reported ${ }^{15,21}$. The most usual treatment of this condition is surgical decompression of the celiac axis by sectioning the median arcuate ligament ${ }^{5,19,22}$. Since the first release of the celiac axis through laparoscopy by Roayaie et al. ${ }^{17}$ in 2000 , this access became the standard treatment of MALS.

Our objective was to evaluate the outcome of laparoscopic treatment of patients with MALS in our hospital.

\section{METHODS}

This prospective observational study included data from six patients with MALS who were subjected to laparoscopic sectioning of the median arcuate ligament at Hospital Nossa Senhora das Graças, Curitiba,PR, Brazil, from October 2014 through June 2019. The study was approved by the Investigation Ethics Committee of the Hospital de Clínicas of the Federal University of Parana, Curitiba, Brazil (Protocol approval number 3.037.086).Informed consentwas waived due to the retrospective study design and collection of readily available clinical data.

\section{Data collection}

The following data were obtained: age, gender, clinical and diagnostic test findings, American Society of Anesthesiologists score (ASA), operative findings and complications, postoperative complications and mortality, hospital stay duration, and hospital readmission. Data were obtained retrospectively from electronic medical records and study protocols. Values were expressed as mean \pm SD (standarddeviation).

The diagnosis of MALS was confirmed in all patients by $\mathrm{CT}$ angiography and/or MR angiography. Other causes of abdominal pain were excluded with extensive medical evaluation, including laboratory tests, electrocardiogram, abdominal ultrasonography, small bowel radiographic study, upper gastrointestinal endoscopy, and colonoscopy.

\section{Surgical procedure}

Under general anesthesia, the patient was placed in supine position in reverseTrendelenburg position with the legs abducted and supported on cushioned spreader bars.
The surgeon stood between the patient's legs. A temporary nasogastric tube was inserted. Thromboembolism prophylaxiswith enoxaparin sodium $40 \mathrm{mg}$ was administered subcutaneouslyat the anesthesia induction in patients $\geq 40$ years old, and in patients with obesity or historyof previous thromboembolism. Antibiotic prophylaxis was not used. Immediately prior to wound incisions, all layers of the abdominal wall of the wounds were infiltrated with local anesthetic (bupivacaine $0.5 \%$ ). The patients received a single intra-operative dose of intravenous parocoxib sodium $40 \mathrm{mg}$, tramadol hydrochloride $100 \mathrm{mg}$, and dipyrone $2 \mathrm{~g}$ for analgesia. A single dose of $4 \mathrm{mg}$ of ondansetron was administered intravenously prior to completion of the procedure to prevent postoperative nauseas and vomiting.

The operation was performed through five trocars inserted in the upper abdomen, similar to that of NissenRosetti procedure. A camera port was inserted on the midline at about $5 \mathrm{~cm}$ above the umbilicus. Four additional trocars were inserted under direct vision into the right and left subcostal areas, left flank, and subxiphoid position.

A retractor was inserted into the subxiphoid trocar to elevate the left lobe of the liver medially and the stomach was retracted to the patient's left side with a Babcock clamp. LigaSure $^{\mathrm{TM}}$ Maryland jaw device (Medtronics, Minneapolis, MN, USA) was employed for tissue dissection and hemostasis.

After gastrohepatic ligamentsectioning, the common hepatic artery and the left gastric artery were dissectedand isolated with a vessel loop for retraction. The arteries were followed to the origin of the celiac trunk. There was no need to dissect the splenic artery.

The right crus was dissected and the median arcuate ligament was identified and divided by energy device and/ or a hook cautery (Figure 1). The anterior surface of the aorta was exposed for about $3 \mathrm{~cm}$. The celiac trunk was completely skeletonized.All fibrotic tissue and nerve plexus overlying the celiac axis were resected.Undue dissection of the esophagus hiatus was not performed in order to avoid postoperative gastroesophageal reflux. Intraoperative ultrasonography was not employed to assess celiac artery flow after decompression.
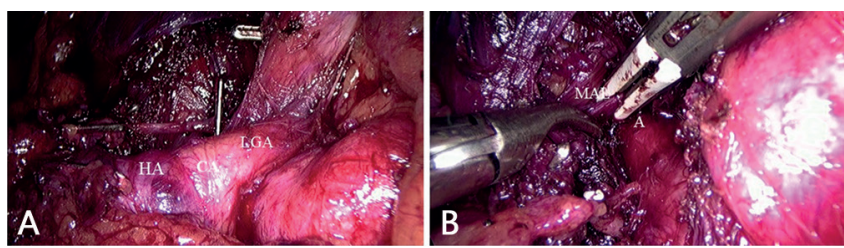

FIGURE 1 - Laparoscopic treatment of median arcuate ligament syndrome: A)common hepatic artery (HA) and left gastric artery (GA) are isolated and dissected andthe celiac axis (CA) is exposed; $B$ ) section of the median arcuate ligament (MAL) with LigaSureMaryland jaw device is shown and exposure of the anterior wall of the aorta $(A)$ is also depicted.

\section{Follow-up}

Patients returned for ambulatory follow-up on the $7^{\text {th }}$ day, and one and three months after operation. Follow-up was extended as needed. Control CT angiography or MR angiography was performed at the $3^{\text {rd }} \mathrm{PO}$ month.

\section{RESULTS}

There were four(66.7\%) women and two (33.3\%) men aged from 32 to 60 years, with a mean age of $43.3 \pm 12.8$ years (mean \pm SD). Clinical manifestations lasted from eight months to three years. Intermittent epigastric pain was referred by 
all patients. Four(66.7\%) patients complained that the pain was postprandial and relieved with fasting. These four $(66.7 \%)$ had weight loss of 3-6 kg, with a mean of $4.8 \pm 1.4 \mathrm{~kg}$. All denied nausea, vomiting and diarrhea. Physical examination was normal in all patients (Table 1).

TABLE 1- Demographic and clinical aspects of patients

\begin{tabular}{|c|c|c|}
\hline Aspects & $\mathrm{n}$ & $\%$ \\
\hline Number & 6 & \\
\hline \multicolumn{3}{|l|}{ Age (years) } \\
\hline Mean $\pm S D$ & $43.3 \pm 12.8$ & \\
\hline Range & & $32-60$ \\
\hline \multicolumn{3}{|l|}{ Gender } \\
\hline Female & 4 & 66.7 \\
\hline Male & 2 & 33.3 \\
\hline \multicolumn{3}{|l|}{ Clinical Presentation } \\
\hline Epigastric pain & 6 & 100 \\
\hline Postprandial pain & 4 & 66.7 \\
\hline Weight loss & 4 & 66.7 \\
\hline \multicolumn{3}{|l|}{ ASA score } \\
\hline I & 4 & 66.7 \\
\hline II & 2 & 33.3 \\
\hline $\begin{array}{l}\text { Prior abdominal } \\
\text { surgery }\end{array}$ & 1 & 16.7 \\
\hline \multicolumn{3}{|l|}{$\begin{array}{l}\text { CT Angiography celiac } \\
\text { axis }\end{array}$} \\
\hline High-grade stenosis & 6 & 100 \\
\hline Poststenotic dilation & 6 & 100 \\
\hline
\end{tabular}

${ }^{*} \mathrm{ASA}=$ American Society of Anesthesiologists

The diagnosis of MALS was confirmed in all patients by CT angiography and/or MR angiography that showed high-grade stenosis of the anterior wall of the proximal celiac axis caused by extrinsic compression of the median arcuate ligament (Figure 2A). Compression was more intense on expiration. Poststenotic dilation was also observed in all patients.
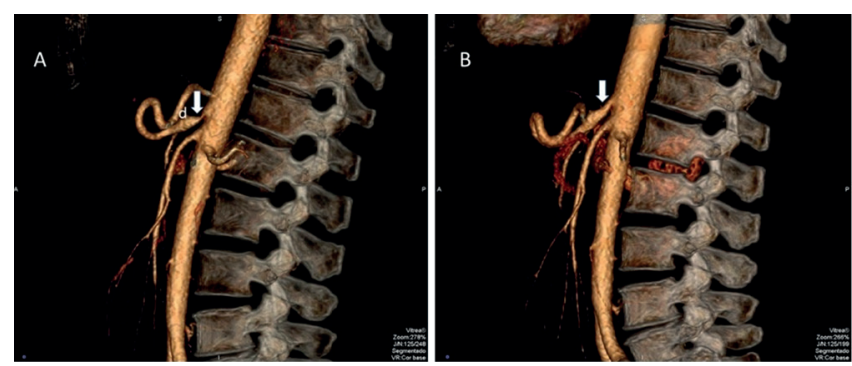

FIGURE 2 - A) Computed tomographic angiography of the abdomen demonstrating severe stenosis of the proximal segment of the celiac axis (arrow) caused by extrinsic compression of the median arcuate on left side, and poststenotic dilation is also depicted with letter " $d$ ";B) normal celiac axis (arrow) is shown after section of the median arcuate ligament on the right side.

Four patients (66.7\%) were ASA I and 2 ASA II (33.3\%).

Surgical procedure was uneventful in all patients. Operative time ranged from 65-120 min, with an average of $93 \pm 22 \mathrm{~min}$. No patient had previous upper abdominal operation. Conversion to open operation did not occur. No operative complication was recorded. All patients were discharged from the hospital within $24 \mathrm{~h}$ after the procedure. The only postoperative complication was urinary retention that occurred in a male. The patient was effectively treated with urinary catheterization. No patient was readmitted to the hospital.

At three-month follow-up, all patients were asymptomatic.
One referred two episodes of mild abdominal pain in the first two months, but he became asymptomatic afterwards. All four patients who referredweight loss prior to the operation, recovered most of the weight. CT angiography and/or MR angiography obtained at that time was normal, with no celiac axis stenosis (Figure 2B).

\section{DISCUSSION}

The median arcuate ligament is a band of fibrous tissue that joins the left and right crura of the diaphragm to form the anterior surface of the aortic hiatusat the level of the $12^{\text {th }}$ thoracic vertebra ${ }^{2}$. The median arcuate ligament usually comes into contact with the aorta above the origin of the celiac axis. However, in some individuals, this ligament may be abnormally low and passes in front of the celiac axis, causing its compression, which is named MALS.

The treatment of MALS consists ofreleasingthe compression of the celiac axis by sectioning the median arcuate ligament ${ }^{5,14}$. The objective is to restore adequate blood flow through the compressed celiac trunk artery. Adequate medium arcuate ligament sectioning may be documented with intraoperative ultrasonography demonstrating the return of the blood flow to normal after sectioning of the ligament ${ }^{12}$

Some authors have suggested that addition of neurolysis is also fundamental to treat the pain associated with MALS ${ }^{11}$. It has been hypothesized that the pain may also have a neuropathic component due to a chronic compression and/ or overstimulation of the celiac ganglion ${ }^{11}$. Neurolysis with complete excision of the celiac nerve plexus may correct the neuropathic component of the pathogenesis of the syndrome.

Surgical treatment may be performed via laparotomy, laparoscopy, or robotic-assisted laparoscopy ${ }^{2,18}$. Laparoscopic decompression of the celiac trunk has become the standard treatment of MALS. Laparoscopic treatment of MALS compared with open operation has several advantages, including less morbidity, less postoperative pain, shorter recovery period, less adhesions, less blood loss, faster return to normal activities, and better cosmetic results ${ }^{2,11}$.

Robotic-assisted approach has also been successfully employed to treat MALS ${ }^{10,18}$. However, due to cost limitation, the experience is still limited, and its use has been restricted to fewermedical centers.

In a literature review, Jimenez et al. ${ }^{9}$ analyzed postoperative outcome of 400 patients subjected to surgical treatment of MALS between 1963 and 2012. Eighty-five percent (339/400) of patients had immediate postoperative relief of symptoms and $6.5 \%(26 / 279)$ had symptom recurrence. The incidence of complications was $11.6 \%$ for laparoscopic approach and $6.5 \%$ for open surgery. The most common complications of laparoscopic approach were bleeding and pneumothorax, and of open surgery were thrombophlebitis, stroke, and gastroesophageal reflux. Laparoscopy conversion to open surgery occurred in 11 of 121 (9.1\%)patients due to bleeding. There were no procedure-related deaths in both approaches. Gastroesophageal reflux disease may develop after surgical treatment of MALS, either after open surgery or laparoscopic approach ${ }^{5,9}$. This is possibly due to inadvertent dissection of the esophageal hiatus. In case of opening of the esophageal hiatus, it should be properly closed ${ }^{12}$.

Diagnosis of MALS may be difficult. Typical symptoms of MALS include recurring epigastric pain, mainly postprandial, nauseas and vomiting, reduced appetite and weight loss ${ }^{11}$. However, an expressive number of patients with MALS do not referrer these typical symptoms. In our series, one third of the patients did not complain of neither postprandial pain nor weight loss.In addition, the typical symptoms may mimic other diseases, such as peptic ulcer and cholelithiasis. Therefore, complete medical evaluation, including laboratory 
exams, endoscopy and ultrasonography should be performed to exclude other medical conditions.

Several authors have confirmed that adequate selection of patients is the most important factor to improve surgical treatment outcome ${ }^{9,22}$. However, selecting patients who are likely to benefit from surgery is a challenge. As in our series, combination of extensive medical evaluation to exclude other diseases and typical findings of high grade of celiac trunk stenosis on angiographyis of paramount importance to diagnose MALS.

Sustained symptom relief has been reported in $80 \%$ to $100 \%$ of patients with MALS who underwent surgical decompression, depending on several factors, including patients' selection and severity of celiac trunk stenosis, 10,19. Roseborough ${ }^{19}$ reported subjective improvement of symptoms in 14 (93\%) of 15 patients treated laparoscopically, with a mean follow-up period of 44.2 months. The followingclinical factors may indicatebetter prognosis: postprandial abdominal pain, age between 40 and 60 years, weight loss greater than 20 pounds, and absence of history of mental illness or alcohol abuse ${ }^{22}$.

\section{CONCLUSION}

Laparoscopic treatment of MALS is safe and effective in relieving the clinical manifestations of patients.

\section{REFERENCES}

1. Balzan SMP, Gava VG, Pedrotti S, Magalhães MA, Schwengber A, Dotto $\mathrm{ML}$, Krebs CR. Prevalence of hepatic arterial variations with implications in pancreatoduodenectomy. ABCD Arq Bras Cir Dig 2019;32:e1455.

2. CoelhoJCU, SilvaJC, DomingosMF, PaulinJAN, Ferronato GF.Laparoscopic treatment of celiac axis compression syndrome: Case Report. ABCD Arq Bras Cir Dig 2015;28:295-6.

3. De'Ath HD, Wong S, Szentpali K, Somers S, Peck T, Wakefield CH. The laparoscopicmanagement ofmedianarcuateligamentsyndromeand its long-term outcomes. J Laparoendosc Adv Surg Tech A2018;28:1359-63.

4. Dunbar JD, Molnar W, Beman FF, Marable SA. Compression of the celiac trunk and abdominal angina. Am J Roentgenol Radium TherNucl Med 1965:95:731-44.

5. Fajer S, Cornateanu R, Ghinea R, Inbar R, Avital S. Laparoscopic repair of median arcuate ligament syndrome: A new approach. J Am Coll Surg 2014;219:e75-8.
6. Harjola PT. A rare obstruction of the coeliac artery: report of a case. Ann ChirGynaecol Fenn 1963;52:547-50.

7. Harr JN, Haskins IN, Brody F. Median arcuate ligament syndrome in athletes. Surg Endosc2017;31:476.

8. Huynh DTK, Shamash K, Burch M, Phillips E, Cunneen S, Van Allan RJ, Shouhed D. Median Arcuate Ligament Syndrome and Its Associated Conditions. Am Surg 2019;85:1162-5.

9. Jimenez JC, Harlander-Locke M, Dutson EP. Open and laparoscopic treatment of median arcuate ligament syndrome. J Vasc Surg. 2012; 56:869-73.

10. Khrucharoen J, Juo YY, Sanaiha Y, Chen J, Jimenez JC, Dutson EP. Roboticassisted laparoscopicmedian arcuateligamentrelease:7-yearexperience from a single tertiary care center. Surg Endosc2018;31:4029-35.

11. Kim EN, Lamb K, Relles D, Moudgill N, DiMuzio PJ, Eisenberg JA. Median arcuate ligament syndrome. Review of this rare disease. JAMA Surg 2016:151:471-7.

12. Miyamotto M, Kanegusuku CN, Okabe CM, Claus CMP, Ramos FZ, Rother A, Gubert APN, Moreira RCR. Laparoscopic treatment of celiac axis compression by the median arcuate ligament and endovascular repair of a pancreaticoduodenal artery aneurysm: case report. J Vasc Bras 2018:17:252-6.

13. NgFH, WaiOKH, Wong AWY, YuSM.Medianarcuateligamentsyndrome. Hong Kong Med J 2016;22:184.e3-4

14. Ramakrishnan $P$, Deuri $B$, Keerthi MS, Naidu SB, Subbaiah $R$, Raj $P$, et al. Laparoscopic division of median arcuate ligament for the celiac axis compression syndrome. Two Case Reports with Review of Literature. Indian J Surg2016;78:163-5.

15. Rebelos E, Cipriano A, Ferrini L, Trifiro S, Napoli N, Santini M, Napoli V. Spontaneous bleeding of the inferior pancreatic-duodenal artery in median arcuate ligament syndrome: do not miss the diagnosis. Oxf Med Case Reports 2019;7:337-9.

16. Ribeiro JBS, Diógenes ECAO, Bezerra PC, Coutinho TAD, Almeida CGF Souza MAN. Lower esophageal sphincter pressure measurement under standardizedinspiratorymaneuvers.ABCDArqBrasCirDig2015;28:174-7.

17. Roayaie S, Jossart G, Gitlitz D, Lamparello P, Hollier L, Gagner M. Laparoscopic release of celiac artery compression syndrome facilitated by laparoscopic ultrasound scanning to confirm restoration of flow. $J$ Vasc Surg 2000;32:814-7.

18. Roberts B, Pevsner R, Alkhoury F. Robotic Approach for Median Arcuate Ligament Release in Pediatrics. J Laparoendosc Adv Surg Tech A 2020;30:92-6.

19. RoseboroughGS.Laparoscopicmanagementofceliacarterycompression syndrome. J Vasc Surg 2009:50:124-33.

20. Santos PV, Barbosa ABM, Targino VA, Silva NA, Silva YCM, Barbosa F, Oliveira ASB, Assis TO. Anatomical variations of the celiac trunk: a systematic review. ABCD Arq Bras Cir Dig 2018;31:e1403.

21. SapadinA,MisekR.AtypicalPresentationofMedianArcuateLigamentSyndromein the Emergency Department. Clin Pract Cases Emerg Med 2019;3:413-6.

22. Sun Z, Zhang D, Xu G, Zhang N. Laparoscopic treatment of median arcuate ligament syndrome. Intractable Rare Dis Res2019;8:108-12. 